\title{
Evolution of Creation from Mythology to Reality: A Multidisciplinary Study into the Roots of Shelley's Frankenstein and Ahmed Sa'adawi's Frankenstein in Baghdad
}

\author{
Karzan Aziz Mahmood \\ Applied Languages, Literature, and Translation \\ Jaume I University, Castellon De La Plana, Spain \\ $\&$ \\ English Language/ College of Languages \\ Komar University for Science and Technology \\ Sulaimaniyah, Iraq
}

Received: 12/19/2020

Accepted: 1/24/2021

Published: 2/24/2021

\begin{abstract}
Shelley's Frankenstein has been considered a literary masterpiece since its publication. Saadawi's Frankenstein in Baghdad is similarly a work of great significance that won the International Prize for Arabic Fiction in 2014. Since its release, the name 'Frankenstein' attached to Baghdad, as a novel title in the mid of the American occupation of Iraq (2005) and its connection to a universal Frankenstein, has been inspiring to the Iraqis and world fiction lovers. What remains essential about this fascination among the readers is in the questions of how and what is the connection between both works. Therefore, this paper attempts to discover the roots of the concept of creation behind Shelley's Frankenstein in 1818 and Ahmed Saadawi's Frankenstein in Baghdad in 2013 from mythology, theology, science, and political reality of Iraq. Besides, the linear evolution in the concept of creation throughout the mentioned areas will be displayed to unfold the origins that lie behind these colossal novels. Understanding that lineage development in the concept and the disputes around it is of great significance to the reader which can empower them to contextualize the novels since apprehending new context is a vital factor for appropriation and intertexuality. As long as there are creators and creatures as the two sides of the same process of creation, therefore, the mentioned concepts will always be discussed throughout this work; including the punishment that both protagonists suffer from as one common consequence.

Keywords: creation, Frankenstein in Baghdad, Frankenstein, mythology, reality

Cite as: Mahmood, k. A. (2021). Evolution of Creation from Mythology to Reality: A Multidisciplinary Study into the Roots of Shelley's Frankenstein and Ahmed Sa'adawi's Frankenstein in Baghdad. Arab World English Journal for Translation \& Literary Studies 5 (1) 187-200. DOI: http://dx.doi.org/10.24093/awejtls/vol5no1.13
\end{abstract}




\section{Introduction}

This Frankenstein permeates a broad heterogeneous history of various disciplines for its origins. In addition, creation which is one of its central themes is rooted in a far history that dates back to the Sumerian and Babylon myths and passing through the Greeks to the modern era. What is captivating about the text is that Shelley's work (1818) appropriates as early as from the title of the novel 'Frankenstein, Or the Modern Prometheus' from pre-history and amalgamates it into her present time. The first word of the novel, which is also the overarching title, is a strange name 'Frankenstein' which has never been known by anyone before. Alongside this an unidentifiable name, the author ascribes a short description to the title 'Modern Prometheus', which, indeed, is not a favor to assist the reader but essentially part of the title. The word Prometheus can be instructive and alleviative to the reader besides a never-heard name with a horrific image of a giant scary monster on the cover.

In such circumstance, one may find himself stuck in a point that cannot be recognized as either past or present. From the Greek mythology, it becomes familiar that Prometheus tricked the God Zeus by stealing fire and giving it to humans. Then, Zeus decided to impose never-ending ferocious kinds of punishment on him. At the start of the novel, the main question is how this Prometheus can be modern or, more vividly, born again? From such a connection between the classical and modern Prometheus, history becomes one of the main fields or lenses to see the work through from the beginning to the end. In immersing into the novel, one can find that this text is centered on modern science or scientific advancements with roots and origins from mythology and theology that make it incomprehensible without them.

On top of that, what is more stimulating is another novel, authored by Ahmed Saadawi, an Iraqi novelist, titled Frankenstein in Baghdad, published in 2013 and winning the International Prize for Arabic Fiction in 2014. Again, it is evident from the title that this could be an appropriation of the Prometheus but an appropriation of the modern Prometheus, not the classical one, whose central word/name in the title 'Frankenstein' is derived but regenerated in Baghdad. In Baghdad, Frankenstein is animated in a setting that is not skeptical of the danger of modern science and politics and harshly criticizes the entire political scene after the United States' invasion of Iraq, a combination of political interests, technology, and the destruction of the country and its population. From the ashes of the war or the military intervention waged by the U.S. and its coalition forces, a creation or a new Frankenstein, in the hands of merely a drunkard junk dealer, is born to put an end to the atrocities and conflicts to realize justice and equality. The events take place in 2005 of Baghdad, the capital city of Iraq, which becomes the most dangerous city of the world for explosions, terrorist acts, sectarian violence, and Western military intervention. As a result, mythology, theology, science, and political reality become the cornerstones or the origins of both Frankenstein/s; hence, the works become relatively unfathomable unless their roots are unfolded; and this is the task that this paper sets to itself concerning the conception of creation with creator, creature, and punishment.

Arab World English Journal for Translation \& Literary Studies 


\section{Literature Review}

The concept of appropriation and adaptation was first coined after the theory of intertexuality has been formulated by Julia Kristeva and Mikhail Bakhtin. In The Oxford Handbook of Adaptation Studies edited by Thomas Leitch, Dennis Cutchins believed that:

One of the questions faced by scholars and students of adaptation is what "adaptation" means in the light of intertextuality. Because an adaptation approach requires that we focus attention on the relationships every text has with other texts, it is in some ways the ideal application of the concepts of intertextuality (Leitch, 2017, p. 71).

Kristeva, for instance, states vividly that "a text is a permutation of texts, an intertextuality in the space of a given text, in which several utterances, taken from other texts, intersect and neutralize one another" (Allen, 2011, p. 11). Furthermore, Bakhtin contended that:

The word in language is half someone else's. It becomes 'one's own' only when the speaker populates it with his own intention, his own accent ... adapting it to his own semantic and expressive intention. Prior to this moment of appropriation the word does not exist in a neutral and impersonal language ...., but rather it exists in other people's mouths, in other people's contexts, serving other people's intentions: it is from there that one must take the word, and make it one's own .... [But] expropriating it, forcing it to submit to one's own intentions and accents, is a difficult and complicated process (McKeon, 2000, p. 349).

Therefore, Bakhtin's concept of appropriation is of great significance in its consideration for the potential influence upon the dynamic evolution of man's imagination and conceptualization. This, in result, will lead to the development of discourse abilities for the expansion of various features that enable one to utilize diverse forms, words, themes, and content in other genres and situations (Lensmire, 1994, p.412).

More specifically, in her outstanding work titled 'Adaptation and Appropriation', Julie Sanders contended that appropriation is substantial in the sense that it often is a fundamental departure from one text to another which becomes either a novel cultural artefact or dwells in a different discipline (Sanders, 2015, p.26). Moreover, the new journey may not be a generic transformation from the previous one but could be against the readers' primary or central text. She, besides, stated that "But the appropriated text or texts are not always as clearly signalled or acknowledged as in the adaptive process. They may occur in a far less straightforward context than is evident in making a film version of a canonical play" (Sanders, 2015, p.26).

Concerning Shelley's Frankenstein and Saadawi's Frankenstein in Baghdad, this paper presents the strong tie that combines them based on appropriation. This first examination of both novels in that light endeavors to prove that the latter appropriated the former and the former from myths and the religious manuscripts. The line of development, in this work, is traced one after the

Arab World English Journal for Translation \& Literary Studies 
other from the notion of creation into the appropriated mythological, theological, scientific, and political origins.

\section{Discussion}

\section{Mythological Roots of Creation}

As the oldest epic of the world, Gilgamesh dates back to the Sumerians for at least a millennium B. C. The story is most famously known for its revolt against death or its strife for immortality. It is not a coincidence that Gilgamesh starts his journey to reach eternity after witnessing his friend, Enkidu's challenging death. In the beginning, Enkidu is created by the gods as the counterpart to halt Gilgamesh, the king of Uruk, who had famously underway tyrannizing his people (George, 2000, p. 1). From this, it becomes evident that Enkidu was created to put an end to Gilgamesh's sovereignty and tyranny upon his people. Contrary to what was planned, they became intimate friends, and then death, as punishment, from the gods had to be imposed onto one of them depending on Gilgamesh and Enkidu's choice. Then, Enkidu chose it and died. His death becomes a prolonged haunting trauma on Gilgamesh. Therefore, he abandons his power to wander in, till his demise, for immortality (Tigay, 2002, p. 4).

This story can be divided into two parts; before and after the death of Enkidu. It means that Gilgamesh has not experienced the death of an intimate person to him in his past time, and his later life after Enkidu's death was haunting him forever into a long journey to the forests, deserts, and mountains. In his scientific endeavors, Doctor Frankenstein is believed to pursue and complete the project of immortality or the animation of the dead, which has lingered and preoccupied man for the last few thousand years since Gilgamesh's epic. From this perspective, Yuval Noah Harari, the living Israeli historian, calls Shelley's Frankenstein scientific mythology because the animated creature goes astray and confronts man; through this message, such scientific creators are warned not to play god. Furthermore, Harari contends that Frankenstein opposes Homo sapiens since: "The pace of technological development will soon lead to the replacement of the Homo sapiens completely different beings who possess no only different physiques, but also very different cognitive and emotional worlds" (Harari, 2015, p. 462). From this perspective, Frankenstein is remarkably relevant to the myth of Gilgamesh in terms of raising the question or concern of immortality or creating a superior being. Westfahl, G., \& Benford, G., V. Hendrix, H. V. Alexander, in their introduction, argued that:

Victor Frankenstein - in wanting not only to rejuvenate aged flesh but to reanimate the flesh of the deceased - goes a good deal further in Frankenstein; or, The Modern Prometheus $(1818,1831)$ than the plot of Gilgamesh, yet the impulse is the same: the preservation of something in the flesh that does not die, that is not merely mortal (Westfahl, 2020, p. 68).

Furthermore, mythological interpretations or fears of the supernatural, gigantic and monstrous creatures have been at work in the human environment, including mans' quest for survival on earth and their interaction and conflicts with other forces within nature. Colavito 
(2008), for instance, believes that the parts or scary features of the monsters were generated from human reality as he argued:

Early humans encountered gigantic animals, such as the woolly mammoth or Gigantopitheus, the ten-foot-gorilla-like creature, both of which died out at the end of the last Ice Age ten thousand years ago. Memories of these monsters filtered down through the ages, and bones of these beasts, and even the long-extinct dinosaurs, may well have given rise to mythologies early monsters (p. 9).

Both Shelley and Saadawi, in their novels Frankenstein and Frankenstein in Baghdad, benefit from those notions that spin around the mythological inspections of creation such as the creators and creatures' characters, the infringement of one's limits such as interfering the zone of the 'Other' (God or nature) by either seeking immortality, stealing fire, sparking life into the dead or collecting and amalgamating discarded body parts, and suffering intolerable punishment at the end as a consequence of the transgression.

The secondary title of Shelley's novel 'Or, The Modern Prometheus' is highly indicative of a precedent Prometheus that heralds this modern one. He is the Greek mythological Prometheus. Frankenstein and the Greek Titan Prometheus are similar in stealing fire from Zeus to grant it to humans or steal secrets from god, which is the principle of life, and then contribute to humans through science. Greek Prometheus is one of the Titans and is well-known for being a trickster by sneaking fire from Zeus to give it to humans (Hesiod, 2006, p. 14). The modern Prometheus is undoubtedly derived from this because light and electricity, in Shelley's work, are the sources of creating the creature by Doctor Victor Frankenstein.

Moreover, the creation of the Greek Prometheus was evil and the counterpart of Zeus. Simultaneously, Victor's creation becomes a monster after he opposes the creator (Hesiod, 2006, p. 14). One of the interesting points of similarity is the punishment-revenge relation between creators. After Prometheus disobeyed Zeus, he had been severely punished by Zeus in the following way:

With breakless, grievous chains he bound Prometheus, then drove Those chains into a pillar's midst so that he couldn't move, And set a broad-winged eagle on the wily one: it flew Down to eat his deathless liver, which always nightly grew Back from what the broad-winged bird that day had swallowed down. (Hesiod, 2006, p. 39)

The above lines, from Theogony, inform the reader that after Prometheus stole fire from Zeus, he had been chained to a rock. Later, an eagle was sent upon him to eat his liver endlessly as his liver was regenerating every night after it was swallowed by the huge eagle every day. This mythical punishment upon Prometheus is repeated in the modern Prometheus and Saadawi's 
Frankenstein as well, as Hadi, the junk dealer, is arrested and charged with violence and murders (Saadawi, 2017, p. 209). The modern Prometheus in Shelley's Frankenstein is doctor Frankenstein who is punished repeatedly by the murders inflicted upon his loveliest people around him. Furthermore, in Frankenstein in Baghdad, Hadi, or the junk dealer who is the creator of the Whatsits-name, suffers the same penalty by losing his regular human face after his face was deformed. This distortion to his face will later transform him into being recognized as a horrific being and causes his arrest by the police eventually since his ugly face is confused with the monster's ugly face. However, many people close to Hadi believe that he is not a murderer. Mahmoud al-Sawadi, for instance, knows that "this was just another massive mistake. They wanted to close the case in any way possible. It was inconceivable that this elderly man was a dangerous criminal" (Saadawi, 2017, p. 210). In the same way that Prometheus was punished forever by chaining him to a rock and his liver eaten by an eagle, Frankenstein loses his entire family. The anguish punishment was also so immense that he eventually regretted his pursuit of knowledge and conducting observations. Likewise, Hadi suffers at the end by losing his human face and being sentenced to life imprisonment by the Iraqi government (Saadawi, 2017, p. 210).

Light is one of the fundamental elements of the mythological conception of creation, impacting the novels. For instance, in Babylon mythology, Tiamat, the master monster (Lambert, 2013, p. 236) was considered evil, or the force of darkness is challenged by the god of light, named Marduk. Its defeat by the god of light is the defeat of darkness by light. These opposing forces of light and dark have played significant roles in mythology and impacted literary science fiction. In the selected novels, this is reflected in the power of lightning and electricity in Shelley's Frankenstein to overcome the darkness of lifeless matter or the dark realm of death. In Saadawi's Frankenstein in Baghdad, the creature returns to life from death because it intends to combat the darkness of the United States invasion, terrorism, sectarian violence, explosions, and the night of inequality.

\section{Theological Roots of Creation}

The battle between the virtuous and wicked forces, creator and creature, and punishment as a consequence of creation by man is benefited from in these fictions as creation, creator, creature, and punishment have been significantly utilized and appropriated with the impact of theological origins. As long as the creator creates beings under the laws of nature, which inherently bear the codes of creation too; therefore, doctor Frankenstein ardently desires to decode the laws and secrets of nature to be able to create a being, as he has stated:

It was the secrets of heaven and earth that I desired to learn; and whether it was the outward substance of things or the inner spirit of nature and the mysterious soul of man that occupied me, still my inquiries were directed to the metaphysical, or in its highest sense, the physical secrets of the world (Shelley, 1992, p. 37).

For instance, in Shelley's Frankenstein, the laws of nature like lightning in control of the divine 
force and electricity in scientific creativity are amalgamated to produce someone mutually as natural as humans and as supernatural as the divine. This combination has been embedded by the natural philosophers of the period as a mixture of old concerns and discoveries as Anstey quotes Peter Harrison:

Three specific claims will be made: (1) that the emergence of the disciplinary category 'physico-theology' was an explicit attempt to address the issue of the place of theology in early modern natural philosophy; (2) that this category is analogous in certain respects to the 'physicomathematics' inasmuch as both represent attempts to renegotiate traditional disciplinary boundaries; (3) that physico-theology resolved vocational tensions specific to this period concerning the extent to which it was legitimate for naturalists to be engaged in theology, and conversely, for clerics to be engaged in the study of nature (Anstey, 2005, p. 165).

In addition, in Cunningham's view, natural philosophy, which is one of the significant evident impacts on Frankenstein, was created by the Christian scholars of the thirteenth century as a defense mechanism for Christianity towards the coming changes perceived as dangerous to religion. The pursuit of immortality could indeed be mythical or even ontological. In contrast, Shelley's novel is a contemporary text that incorporates many scientific discoveries so that natural philosophy was concerned with those sciences. Therefore, Frankenstein's concern of creation is tilting between theological and scientific beliefs and progressions.

The creator is exceptionally passionate and curious about his observation as any other scientist. However, he eventually becomes regretful of his project and its consequences, specifically, and of what knowledge can bring to humans' lives. Sublimity, revenge, and horror of the creature are altogether the emblem of man's fear to what danger may science lead man; or what punishment could await man in such scientific discoveries in the view of theology.

Creation, punishment, and the conflict between the characters in both novels are intermingled in ways that they can be perceived as the embodiment of theology in the concrete world. Ludwig Feuerbach, for instance, argued that "The task of the modern era was the realization and humanization of God - the transformation and dissolution of theology into anthropology" (Feuerbach, 1972, p. 3). This material alteration in the conception of creation and punishment into this concrete world is brought forth due to the scientific and technological advancements that have given excessive powers to man over nature; or in other words, it is the realization and humanization of theology. Once a scientific creation crosses the natural boundary, as Shelley's Frankenstein indicates, it can be a threat to transgress the creator's rein of control because the creator is bound with the natural laws, and his creation could be beyond or above the natural laws.

The idea of the natural law could demonstrate the conflict within the modern world as it exists between theological and scientific faiths. For example, the priests did not allow their bodies 
to be dissected after their death. Therefore, the disintegration of their bodies, which was merely an act of anatomical segmentation, was perceived to be against God's consecrated creation of humankind. Koveshnikov, in his Human Anatomy, states that:

the medieval period, which began after the Roman Empire (IV-XIV), was marked by the ultimate power of the Church and downfall of sciences and culture. The social system of the period was feudalism. In Europe, Catholic Church declared the dominion of galenism dogmatizing the works of Galen. The dissection of the dead bodies was forbidden (Koveshnikov, 2006, p. 30).

The theological interpretation could influence doctor Frankenstein's enthusiasm for knowledge, scientific discovery and his punishment that after Eve eats the fruit from the tree of knowledge, she and Adam are punished by god by expelling them from the Garden of Eden. The Oxford Bible Commentary, in this course of the discussion, clarifies that:

In its conversation with the women (3: ib-5), the serpent asserts that God's threat of immediate death for eating the fruit of the tree of knowledge (2:17) is a false one. The acquisition of the knowledge of good and evil (that is, of wisdom) will lead instead to the human pair becoming 'like God'. There is truth in what the serpent says: eating the fruit does not result in immediate death, and although the man and the woman do not become wholly like a god since they still lack immortality, god fears that if they also eat the fruit of the tree of life, they will obtain full divine status (3:22). But the serpent fails to say it will be the actual fate. (Barton, 2001, p. 44)

After doctor Frankenstein suffers severely from the punishments inflicted upon him for the quest and pursuit of knowledge or the science of the Gods, he despairingly states:

Learn from me, if not by my precepts, at least by my example, how dangerous is the acquirement of knowledge and how much happier that man is who believes his native town to be the world, than he who aspires to become greater than his nature will allow (Shelley, 1992, p. 52).

\section{Scientific Roots of Creation}

Yuval Noah Harari, the living Israeli historian and scientist, in regards to Shelley's Frankenstein as a science fiction novel and specifically in relation to its roots, states that:

this is why the Gilgamesh project is the flagship of science. It serves to justify everything that science does. Doctor Frankenstein piggybacks on the shoulders of Gilgamesh. Since it is impossible to stop Gilgamesh, it is also impossible to stop Doctor Frankenstein (Harari, 2015, p. 464).

Besides, the above argument that links the 1818 Frankenstein to the few thousand-year-old text of 
Gilgamesh myth as a warning that might prevent and halt the scientific discoveries of the emerging progressive period since these novel innovations may pave the way to endanger the future lives of humankind. To Harari, the project of Gilgamesh is reproduced in Shelley's novel in the light of the fear that the on-going advancements and human creations can introduce new and severe suffering and punishment to humanity.

Despite such a connection in terms of the theme of danger in human creation as transgression, it is more evident that Frankenstein as a text is born in an epoch that is replete with brilliant minds and inventions. Hence, the scientific reality of the prior centuries in which Frankenstein is born is more influential than a myth that dates back a few thousand years. Therefore, if this text manifests contradictory forces, it is within the reality between the old endangered beliefs and/by the new scientific alterations. For instance, Copernicus, Kepler, Descartes, Galileo, Newton, and Franklin are among those giant minds of the fifteenth to eighteenth centuries.

Charles Darwin's father, Erasmus Darwin, 29 years before the publication of Shelley's work, had released a famous work, The Botanic Garden, in which he clearly states that the earth was not created by God but originated from a volcanic eruption in the sun (Garfinkle, 1955, pp. 377-378). This perspective towards creating the earth is a secular and radical one that does not shake merely the mythological and theological creation theories but is also a merciless strike against the creation of man, its position, and its purpose in the world to the entire preceding assumptions.

Another remarkable breakthrough behind the novel is Franklin Benjamin's discoveries in electricity half a century before Mary Shelley's birth. He had proposed a fascinating experiment in 1752 called the Kite Experiment as the following:

As early as November 7, 1749, or about three years after he had first seen a Ley den jar, Franklin concluded that lightning was a manifestation of electricity. He was then forty-three years old. In Letter V of his Experiments, he gives at length his conclusions. In sections 9, 10, and 11, he confuses phosphorescence with electricity while advancing views on the electrical origin of clouds. In paragraph 33 of the same letter, Franklin advances the concussion theory of rain and he might be regarded as the first of a long line of would-be rainmakers who seek to connect explosive waves with precipitation. I mention this matter here because he unquestionably had noticed the rain gushes after near lightning flashes (McAdie, 2020, p. 188).

When doctor Frankenstein was only fifteen years old and staying in Belrive at a house, he noticed a striking thunderstorm hitting a tree, and after the natural incident is complete, he perceived this:

And so soon as the dazzling light vanished, the oak had disappeared, and nothing remained 
but a blasted stump. When we visited it the next morning, we found the tree shattered in a singular manner. It was not splintered by the shock, but entirely reduced to thin ribbons of wood. I never beheld anything so utterly destroyed (Shelley, 1992, p. 40).

Despite the intriguing experience at Belrive, he was acquainted with electricity discoveries. Still, a knowledgeable man of natural philosophy who accompanied him on occasion explained the incident with the lens of a new theory about electricity and galvanism. This man and the theory became a significant factor for a flashback as doctor Frankenstein states, "all that he said threw greatly into the shade Cornelius Aagrippa, Albert Magnus, and Paracelsus, the lords of my imagination" (Shelley, 1992, p. 40).

Once Victor Frankenstein's absolute passion for the secrets of life emerges, he soon immerses himself into intensive self-study as a child, witnesses real experience when he is fifteen and leaves for university studies in the natural sciences when he becomes seventeen years old. In the introduction of one of his essential preliminary lectures at Ingolstadt University, professor doctor Waldman greatly impresses Frankenstein by stating that:

The ancient teachers of this science,' said he, 'promised impossibilities and performed nothing. The modern masters promise very little; they know that metals cannot be transmuted and that the elixir of life is a chimera but these philosophers, whose hands seem only made to dabble in dirt, and their eyes to pore over the microscope or crucible, have indeed performed miracles (Shelley, 1992, p. 46).

The progress in modern chemistry, physiology, physics, and mathematics was a new journey in natural philosophy as the secular sciences' birth. This is a strong indication that the bourgeois families whose sons did not have to work could undertake such studies in universities. Above all, this goes hand in hand with the British capitalist development in the middle of its industrial and scientific revolutions. It is precisely after the pertaining advancements to the revolutions that Karl Marx commences his criticism towards the capitalist system and Britain, particularly for its industrial revolution. Hesitation in the heart of Shelley's novel regarding the inherent threat within the developing capitalism was the control of science in the advantage of capital and exploitation of the workers. From this perspective, the Marxist philosopher, John Holloway, interprets the British Frankenstein's monster as capitalism that sucks the blood of the workers and endangers human lives. For instance, after Victor Frankenstein creates a being as an actual act of creativity, it becomes independent and eventually controls its creator's life with his absolute exploitative power. For Holloway, this indicates to the entire mankind as the creator of capitalism and later being controlled and manipulated by the monsterity of its creation: capitalism (Holloway, 2010, p. 229). Regarding the danger of capitalism manipulation of science, David Harvey, the great living Marxist philosopher, contends that science is politically ideological (Harvey, 1974, 256).

Arab World English Journal for Translation \& Literary Studies 


\section{War Roots of Creation}

It is manifest from Ahmed Saadawi's title 'Frankenstein in Baghdad' that he intertexualizes or appropriates Shelley's Frankenstein. The main parts that are appropriated include the process of creation, creator and creature, guilt, innocence, and punishment in a way that benefits from mythology and theology, science, and the destruction of war. It could be said that the Iraqi author has revolutionized the original text for the following reasons. The protagonist is not a canonical doctor-like figure; contrary to Doctor Victor Frankenstein, who produces a creation scientifically, science has never been a concern of the junk dealer. Instead, he, Hadi, is merely a junk dealer or scavenger who combines the body parts of innocent blown up people and, with no clue of science, stitches them together. Frankenstein aims at sparking life into the dead or reanimating it. At the same time, Hadi solely intends to give a proper burial to the dead as a whole body and save them from being treated like rubbish by the government after they are torn up into the air by the terrorists as he states "I made it complete so it would not be treated as trash so that it would be respected like other dead people and given a proper burial" (Saadawi, 2017, p. 10).

The novel takes place in Iraq, Baghdad, and the mid of 2005. The U.S. invasion of the country in 2003 has turned Iraq, mainly the capital city Baghdad, to be the most dangerous place in the world. Jessica Stern at Harvard University and Megan K. McBride at Brown University argued that the American military intervention in 2003 was supposed to prevent Iraq from becoming the cradle for terrorism. Still, there have been seventy-eight terrorist assaults during the first year of the U.S. army in the country from 2003-2004. More shockingly, from their stay in the country from 2004-2005, the terrorist attacks have escalated four times to 302 assaults. In another article, How America Created a Terrorist Haven, in August 2003, Jessica Stern argues that "Yesterday's bombing of the United Nations headquarters in Baghdad was the latest evidence that America has taken a country that was not a terrorist threat and turned it into one" (Stern, 2003, p. 1). The charges against Saddam Hussein's regime for having mass destruction weapons were proven mere accusations.

The U.S. war waged against Iraq had caused hundreds of thousands of victims. A unique survey conducted by the Iraq Family Health Survey Study Group titled Violence-Related Mortality in Iraq from 2002 to 2006 concludes that "in mid-2006 estimated that an additional 654,965 persons had died during the 40 months since the U.S.-led invasion, as compared with prewar numbers. This number included 601,027 excess deaths due to violence".

This has entirely created a theatre of diverse violence and atrocities that have made Iraq a haunting nightmare of the world's collective unconsciousness. Explosions and bombs become common means of terrorist acts in the capital city, especially in 2005 which was one of the peaks. In such a threatening context, the author of the Iraqi Frankenstein working as a reporter for the Arabic BBC in 2005, visits one of the morgues in Baghdad where he witnesses a young man entering with a cry for his brother's body just been killed in an explosion. In response, the morgue chief with a hand refers to a piece of a dead body, which is thrown in a corner, to be his brother.

Arab World English Journal for Translation \& Literary Studies 
After the dead man's brother shockingly asks for the rest of his brother's body parts, the man in charge responds to him by saying that he can take whatever part to make an entire body for himself (Hankir, 2018). This novel culminates in transforming the theme of scientific creation to the destruction of war and the U.S. occupation of Iraq in particular. The first body that Hadi pieces it together reanimates one morning and flees. This creature then sets the task of realizing justice upon himself by killing all the guilty people. This nameless man, called Whats-its-name later, turns dangerous for the state and government as they cannot kill him. Eventually, its creator will be confused by the security forces for losing his human complexion and becomes as ugly as his nonhuman creation. Therefore, the same conception of punishment over the creator due to his creative act is utilized.

Saadawi's Frankenstein is influenced by the other origins mentioned before. He borrows the same characters and engages with the salient themes of creation, creator, creature, punishment, guilt, innocence, and so on. The revolutionization of the text in terms of the roots includes many. Still, it climaxes in transforming the theme of scientific creation to the destruction of war and the Iraq occupation. The outstanding indication of this destruction in the novel is embodied in the character of Whats-its-name, whose body is a combination of the disintegrated parts of other peoples' blown-up bodies and the disintegration of Iraq as a whole from the previous co-existing body.

Therefore, the absolute alteration of the creation concept in this novel in the AmericanIraqi war zone is transforming into destruction and disintegration. In result, it produces another origin for the evolution of the conception of creation in the history of Frankenstein. This was, on the one hand, formed in England 1818 when the opposing forces of science and theology intersected, and Frankenstein in Baghdad in Iraq and the war destruction, on the other hand.

\section{Conclusion}

In the connection between Frankenstein and Frankenstein in Baghdad, the most striking point is perhaps about the question of how and what combines both works. To this paper, the examination of the concept of creation in light of appropriation and intertexuality has been the central tie which derives its origins from mythology, theology, science and reality as they are replete with such stories. In contrast, with the emergence of modern era, scientific discoveries and doctrines have begun replacing or doubting the old beliefs and foundations of creation. Shelley's Frankenstein manifests the conflict between the power of supernatural creation and the developing science of the period that promised the fulfillment of all the previous dreams. Therefore, Shelley reproduces the ancient origins or roots of man's transgression from the mythological and theological gods and embodies them with modern science's power. The transformation of Prometheus to the modern Prometheus, lightning to electricity, God as the divine creator, to Victor Frankenstein as the earthly creator are evident examples of those origins. While this Frankenstein is appropriated into Frankenstein in Baghdad, the same origins are utilised with modern war and destruction as another new origin to Frankenstein. This last Frankenstein is produced in Iraq and

Arab World English Journal for Translation \& Literary Studies 
precisely after the U.S. invasion of the country, which occasions its disintegration and turns it into bloodshed and terrorism. As a result, this paper unfolds the origins of Frankenstein/s in mythology, theology, science, and the destruction of Iraq by the U.S. military intervention.

\section{About the author:}

Karzan Mahmood obtained B A and M A in Iraq and the U K and is currently a Ph.D. student in Spain, all in English literature. His research interests include Romantic Sublime, Intertextuality, Appropriation, Literary Theory and Criticism, Marxism, and Postmodern Studies. He has been teaching English literature from Komar University for Science and Technology since 2016. https://orcid.org/0000-0001-8860-5781

\section{References}

Allen, G. (2011). Intertextuality: Origins: Saussure, Bakhtin, Kristeva (p. 11). Routledge. Anstey, P. R, \& Schuster, J. A. (2005). The Science of Nature in the Seventeenth Century: Patterns of Change in Early Modern Natural Philosophy (p. 165). Dordrecht: Springer Netherlands. Barton, J., \& Muddiman, (2001). Oxford Bible Commentary. Oxford: Oxford University Press. Colavito, J. (2008). Knowing Fear: Science, Knowledge and the Development of the Horror Genre. Jefferson, NC: McFarland and Co.

Feuerbach, L. (1972). Principles of Philosophy of the Future. 1st ed. The Fiery Brook. Available at https://rowlandpasaribu.files.wordpress.com/2013/09/ludwig-feuerbach-principles-ofphilosophy-of-the-future.pdf

Garfinkle, N. (1955). Science and Religion in England, 1790-1800: The Critical Response to the Work of Erasmus Darwin. Journal of the History of Ideas, 16(3), 376-388. https://doi.org/10.2307/2707638.

George, A. (2000). The Epic of Gilgamesh (2 ${ }^{\text {nd }}$ ed.). London: Penguin Classics.

Hankir, Z. (2018). Ahmed Saadawi wants to tell a new story about the war in Iraq. Literary Hub, June 19. Available at https://lithub.com/ahmed-saadawi-wants-to-tell-a-new-story-aboutthe-war-in-iraq/

Harari, Y. (2015). Sapiens: a Brief History of Humankind. London: Vintage.

Harvey, D. Population, Resources, and the Ideology of Science. Economic Geography, 50(3), 25677. https://doi.org/10.2307/142863.

Hesiod, H. (2006). Theogony and Works and Days. Michigan USA: The University of Michigan Press.

Holloway, J., \& Benemérita, P. (2010). Crack Capitalism. Universidad Autónoma de: Pluto Press.

Koveshnikov, B., \&, Romensky, L. (2006). Human Anatomy (1st Vol). Ukraine: Lugansk.

Lambert, W.G. (2013). Babylonian creation myths. Winona Lake: Eisenbrauns.

Leitch, T. (Ed.). (2017). The Oxford handbook of adaptation studies. Oxford University Press. Lensmire, T. J., \& Beals, D. E. (1994). Appropriating others' words: Traces of literature and peer culture in a third-grader's writing. Language in Society, 411-426. 
AWEJ for Translation \& Literary Studies Volume, 5 Number 1. February 2021

McAdie, A. (p. 188). The Date of Franklin's Kite Experiment. Proceedings of the American Antiquarian Society, N.S, 188, 188-205. Available at https://www.americanantiquarian.org/proceedings/44806729.pdf.

McKeon, M. (Ed.). (2000). Theory of the novel: A Historical approach. JHU Press.

Saadawi, A. (2017). Frankenstein in Baghdad. Translated by Jonathan Wright. New York: Penguin books.

Sanders, J. (2015). Adaptation and appropriation. Routledge.

Shelley, M. (1992). Frankenstein: the Modern Prometheus. Harmondsworth: Penguin.

Stern, J. (2003). How America created a terrorist haven. New York Times, 20.

Tigay, J. (2002). The Evolution of the Epic of Gilgamesh ( $2^{\text {nd }}$ ed.). Wauconda, Illinois USA: Bolchazy-Carducci Publishers.

Westfahl, G., \& Benford, G., V. Hendrix, H. V., Alexander, J. (2020). Science Fiction and the Dismal Science: Essays on Economics in and of the Genre. Jefferson, NC: McFarland \& Company, Inc., Publishers. 